\title{
Translational HIV-1 research: from routine diagnostics to new virology insights in Amsterdam, the Netherlands during 1983-2013
}

Antoinette C van der Kuyl ${ }^{1 *}$, Margreet Bakker', Suzanne Jurriaans ${ }^{2}$, Nicole KT Back², Alexander O Pasternak, Marion Cornelissen ${ }^{1}$ and Ben Berkhout ${ }^{1}$

\begin{abstract}
An HIV-1 diagnostic laboratory was established in the Academic Medical Center (AMC) of the University of Amsterdam after the discovery of human immunodeficiency virus (HIV) as the cause of the acquired immunodeficiency syndrome (AIDS). The first AIDS patients were diagnosed here in 1981 and since 1983 we have tested the samples of 50992 patients using a variety of assays that greatly improved over the years. We will describe some of the basic results from this diagnostic laboratory and then focus on the spin-off in terms of the development of novel virus assays to detect super-infections and ultra-sensitive assays to measure the intracellular HIV-1 RNA load. We also review several original research findings in the field of HIV-1 virology that stem from initial observations made in the diagnostic unit. This includes the study of genetic defects in the HIV-1 genome and time trends of the replication fitness over 30 years of viral evolution, but also the description of novel HIV-1 variants in difficult-to-diagnose clinical specimen.
\end{abstract}

Keywords: HIV-1, Patient care, Viral load assays, Genotyping, Novel subtypes, Fitness, Superinfection, Seroreversion

\section{Introduction}

The acquired immunodeficiency syndrome (AIDS) was recognized by the Centers for Disease Control (Atlanta, USA) in 1981 [1]. The causative agent, the human immunodeficiency virus (HIV) was isolated first by BarréSinoussi et al and described as lymphadenopathyassociated virus (LAV) in 1983 [2], and also by Gallo et al, who named it human $\mathrm{T}$ lymphotropic virus type III, HTLV-III [3]. The complete nucleotide sequence of this novel retrovirus was reported almost two years later $[4,5]$. The development of antiretroviral compounds in the next decade changed AIDS from a lethal infectious disease to a chronic condition. The first antiretroviral drug, azidothymidine (AZT, zidovudine), a nucleoside analogue targeting the reverse transcriptase (RT) enzyme, was approved by the US Food and Drug Administration in March 1987 for clinical use in AIDS patients [6], and many others rapidly followed. AZT was administered to Dutch AIDS patients

\footnotetext{
* Correspondence: a.c.vanderkuyl@amc.uva.nl

${ }^{1}$ Laboratory of Experimental Virology, Academic Medical Center of the University of Amsterdam, Amsterdam, the Netherlands

Full list of author information is available at the end of the article
}

since mid-1987 as monotherapy [7,8]. After that, serial monotherapy with novel RT inhibitors was the standard of care, until the development of protease (PR) inhibitors enabled combination therapy to be established [9]. Large scale introduction of HAART (Highly Active AntiRetroviral Therapy), now designated as combination antiretroviral therapy or cART, into the clinical practice in the Netherlands started in June 1996, when the PR inhibitors indinavir, ritonavir, and saquinavir became widely available [10].

From the early days on, it was appreciated that the main feature of AIDS is a steady decline of CD4+ T-cells circulating in peripheral blood, causing a significant change in the CD4+/CD8+ T-cell ratio (see: [11]). CD4+ (and CD8+) T-cell counts were hence used to monitor disease progression. Furthermore, individuals infected with HIV have benefited tremendously from the advances in molecular techniques that became available in the 1980s, which markedly increased the virus assays available for patient care. Plasma viral RNA load (pVL) was found to be another predictor of disease progression [12], and pVL determination became part of routine 
patient care. After the introduction of antiretroviral drugs, determination of drug-resistance mutations in patient-derived viral genomes by PCR amplification and sequencing of the protease-reverse transcriptase genes (PR/RT genotyping) became yet another standard clinical test $[13,14]$.

This review focuses on the HIV-1 epidemic in the Netherlands and the diagnostics and research performed at the AMC hospital of the University of Amsterdam. However, we should point out that the HIV research field developed rapidly through international efforts that were conducted simultaneously by many centers of clinical care and research. In fact, competition between these international centers has been an important driver of scientific advancement in the area of HIV research.

\section{Review}

Basic numbers of HIV-1 diagnostics at the AMC hospital The first three diagnosed Dutch AIDS patients; all hospitalized in the AMC in Amsterdam were described in March 1983 [15-17], two months before the discovery of
HIV was published. Two of these patients had been seen by clinicians for AIDS-related complaints since 1981, the third was first seen in 1982 and was probably infected outside the Netherlands [16].

After the discovery of HIV in 1983, serum antibody ELISA and Western blot tests were developed that could diagnose HIV-infected individuals [18]. The total number individuals tested in the AMC from 1984-2012 for antibodies against HIV (both with positive and negative outcome) is plotted in Figure 1A. The number of individuals tested has increased substantially from the 1980s till recent years, but is levelling off in recent years. Figure $1 \mathrm{~B}$ shows the number of HIV antibody tests performed in relation with the most likely transmission route according to the risk group: men having sex with men (MSM) (homoor bisexual men), heterosexual contacts (mainly immigrants), (intravenous) drug users (DU), recipients of blood products (haemophiliacs, needle accidents ) and motherto-child (vertical) transmission (MTCT). In most cases, the risk group is not registered, so that patient numbers shown are much lower than in Figure 1A. Peaks in 1984/

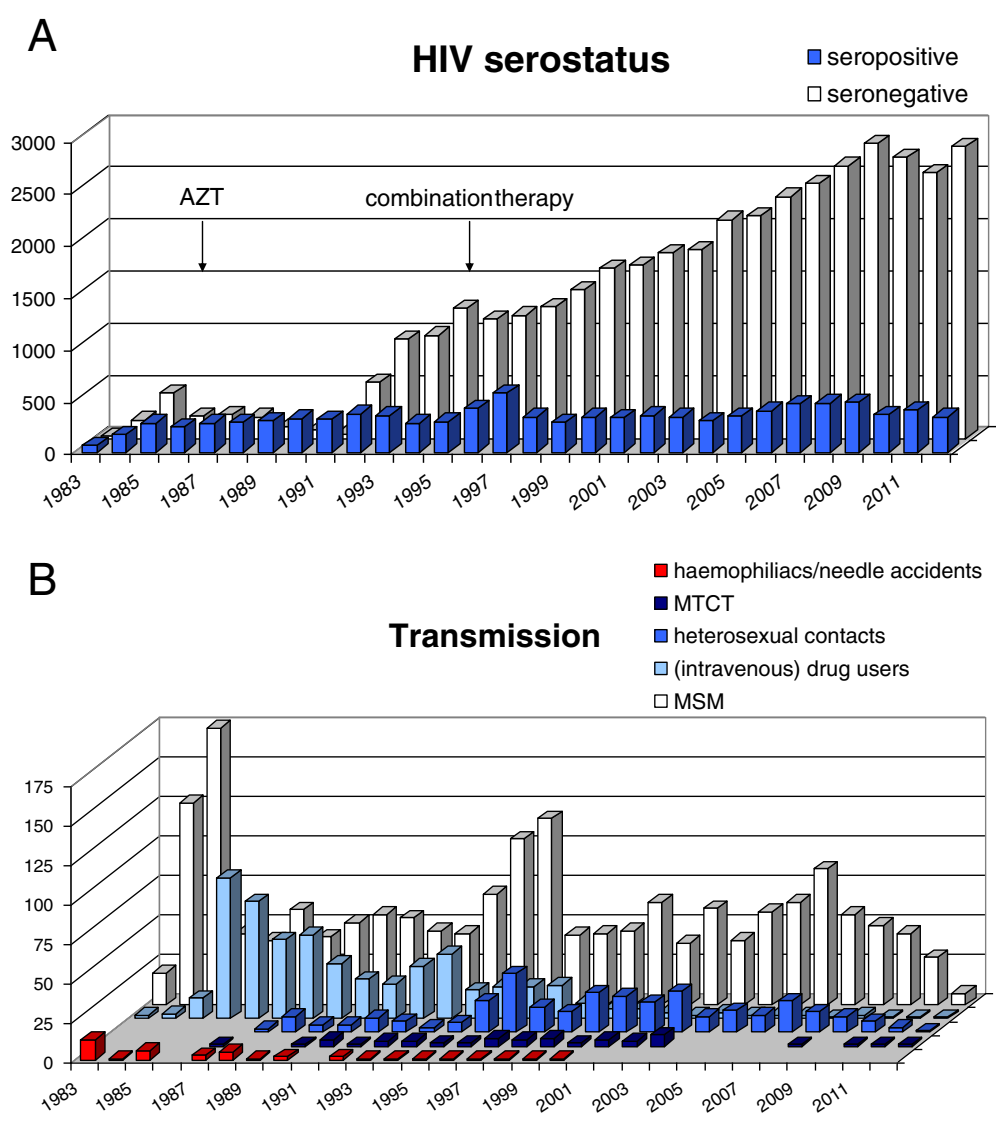

Figure 1 HIV antibody-tests at the AMC. A. Numbers of individuals tested for HIV-infection using serology at the AMC (Amsterdam, the Netherlands) from 1983-2012. The introduction of antiretroviral treatment (AZT/zidovudine and CART) is indicated by arrows. Between 1984 and 1992/1993, patient data were mainly recorded in written documents and not always filed later in databases. Therefore, the number of tests in those years is probably an underestimation as not all data could be retrieved. B. Numbers of HIV positive patients tested in the AMC in Amsterdam from 1983-2012 according to the most likely route of HIV transmission. 
1985 and 1998/1999 in numbers of MSM correspond with active recruitment for the Amsterdam Cohort Studies on HIV/AIDS (see below). The AIDS epidemic was initially recognized as being confined to the MSM risk group, patients with haemophilia who received blood products and intravenous drug users, so testing of other risk groups occurred infrequently in the early years of the epidemic. After some years it was realized that other groups such as heterosexuals and children born to infected mothers were also at risk, and the testing policy was expanded accordingly. In 2001, the Municipal Health Service started to offer HIV testing to pregnant women in the Amsterdam area [19]. However, as most refused the test, opt-out testing (patients may elect to decline or defer testing after being notified that the test is routinely performed) was applied in 2003 [19]. Since 2004, all pregnant women in the Netherlands are being tested for HIV using this opt-out policy [20]. Since then, MTCT rates of HIV have decreased in the Netherlands from 5-10 per year to less than 1 per year (Figure 1B). In fact, all children that tested HIV-positive after 2003 were immigrants from nonWestern countries.

Testing for HIV-1 is done mainly at outpatient clinics for sexually transmitted infections. These centers include the Municipal Health Service in Amsterdam, where $>20.000$ HIV tests were performed per year in recent years [21]. Since 2005, HIV rapid tests - based on HIV-antibody detection in saliva (for a review, see [22]) - have been introduced that dramatically increased the number of tests performed [21]. In addition, HIV-tests are requested by general practitioners (GPs), but numbers are much lower. Approximately 11 HIV-tests/10.000 patients per year were GP-requested in 2009 [23]. Self-testing is another way to determine one's HIV status. A survey under internet users in the Netherlands showed that 71/4416 (1.6\%) respondents had ever performed an HIV/AIDS self-test, of which only $9 \%$ had used a true home-test [24].

HIV screening assays performed at the AMC are mainly done on patients visiting the outpatient clinics, hospitalized patients, on patients visiting GPs in the neighbourhood and on individuals participating in the Amsterdam Cohort Studies (see below) [25].

HIV-1 infections in the Netherlands are mainly found in MSM. Of the 16,169 HIV-infected patients in clinical care in June 2012, $80 \%$ are men of which at least $74 \%$ have been infected through homosexual contact according to the HIV Monitoring Foundation Report 2012 [26]. However, HIV-testing, both at the Municipal Health Service and as requested by GPs mostly involves heterosexuals, as high-risk MSM often opt-out [21,23]. It has been estimated that $20-40 \%$ of HIV-infected individuals in the Netherlands are unaware of their HIV status [21].

The numbers of HIV-1/2 screening antibody tests and confirmatory Western blots and other confirmatory assays performed in the AMC since 1996 are plotted in Figure 2A. Antigen tests (HIV-1 p24) became available in 1986 and have been used as a prognostic marker [27,28]. pVL assays became part of the standard patient care around 1996 (Figure 2B). The early peak in the number of assays performed around 1998-1999, reflects the intense testing of the few available patients using a variety of assay formats. Subsequent peaks reflect the increase in the number of patients, usually being tested with a single specific test that screens for both HIV antigen and anti-HIV antibodies.

After the introduction of antiretroviral regimens that contained multiple drugs from 1997 onwards, drugresistance testing was implemented in patient care to monitor the development of drug-resistance mutations, which is usually due to low compliance. This test also allowed one to investigate the pre-existence of drugresistance mutations in plasma virus before the start of treatment, so that drug prescription could be adjusted accordingly. Numbers of sequence tests performed are shown in Figure 2C. In recent years, due to the introduction of antiretroviral drugs targeting viral proteins other than PR or RT, sequencing of integrase (IN) and envelope (ENV) gene fragments was performed for a limited number of patients.

Overall, we witnessed a steady increase over time of the number of assays performed, but also a more recent drop. This drop mainly reflects decreasing clinical budgets in this economically challenging period. Consequently, fewer assays are being requested.

\section{The Amsterdam Cohort Studies}

Subsequent analysis of a cohort of homosexual men participating in a hepatitis B virus (HBV) vaccine efficacy trial between 1980 and 1982 suggested that HIV was introduced in the homosexual population in Amsterdam at the end of the 1970s [29]. The Amsterdam Cohort Studies on HIV/AIDS (ACS) were started in October 1984, initially as a two-year prospective study of HIV incidence in MSM $[30,31]$, then as an open, prospective cohort study on HIV. Later, DUs were also included in this cohort, but the HIV1 incidence in drug users has declined steadily in the Netherlands from 1986 onwards to less than 1.0/100 person-years in 2010 with no new seroconversions after 2009 [32,33]. From 2003-2010, adult patients with primary HIV-1 infection (PHI) from 13 Dutch treatment centres were recruited in a cohort study coordinated by the AMC to analyse the effect of early cART treatment on disease progression [34]. Patient samples from both the ACS and the PHI cohort were subsequently used for in-depth studies of HIV infection characteristics that will be summarized below.

Similar cohorts for the study of HIV infection and AIDS were recruited in other countries, such as the Multicenter 


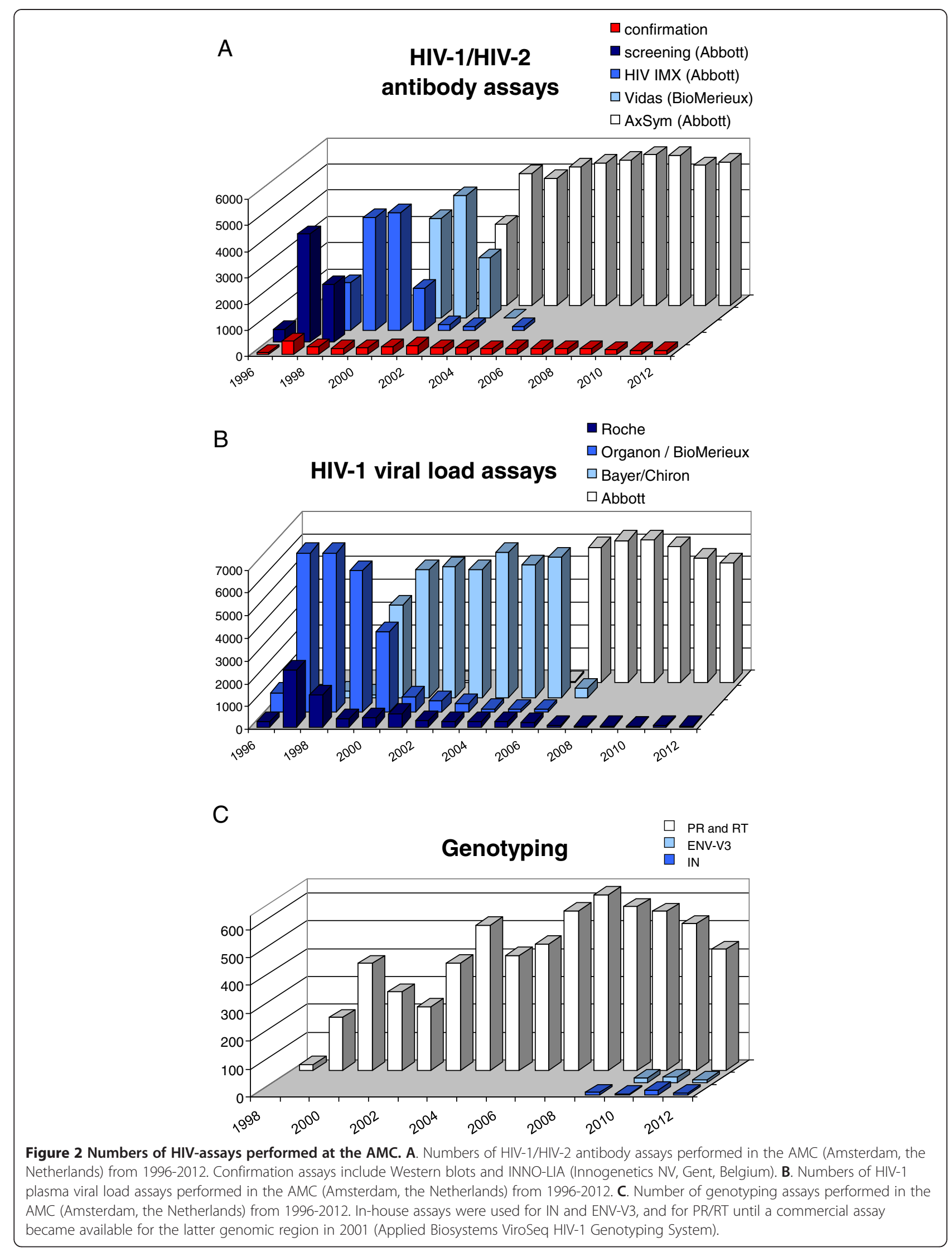




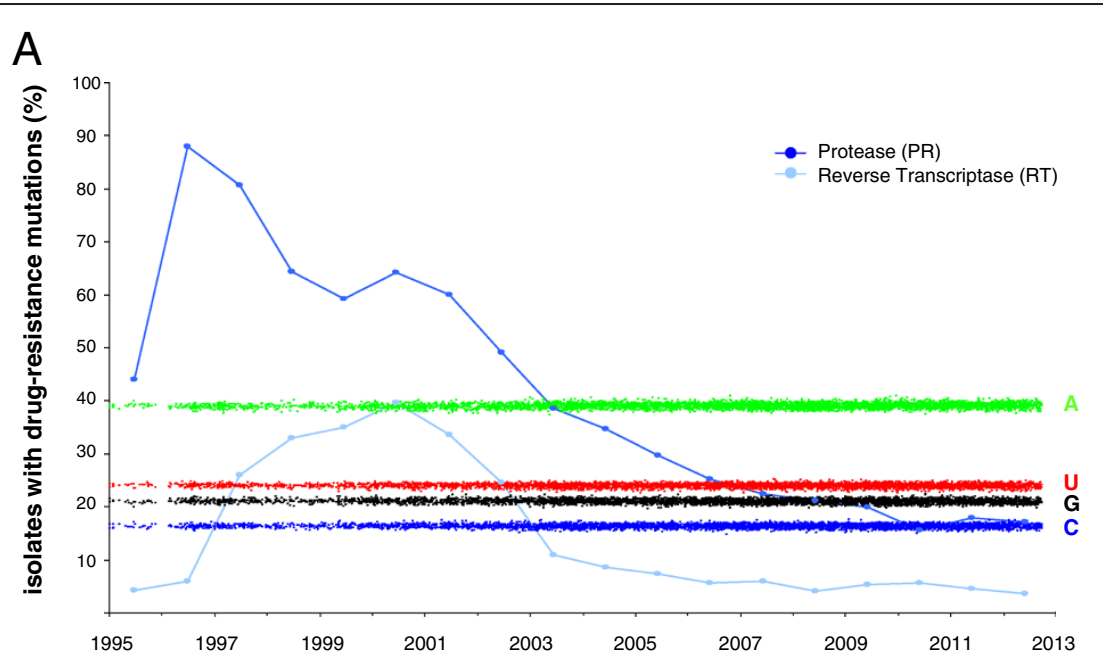

B

number of PR sequences

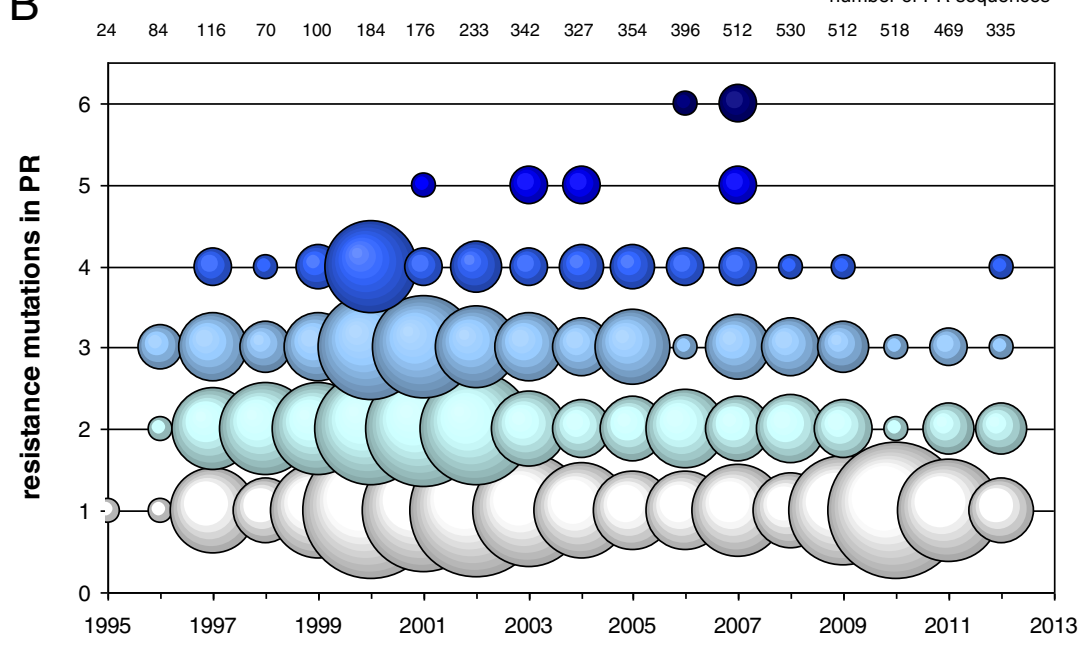

C

number of RT sequences

$\begin{array}{lllllllllllllllllll}C & 25 & 83 & 108 & 70 & 98 & 173 & 172 & 230 & 345 & 329 & 357 & 398 & 514 & 535 & 497 & 521 & 469 & 333\end{array}$

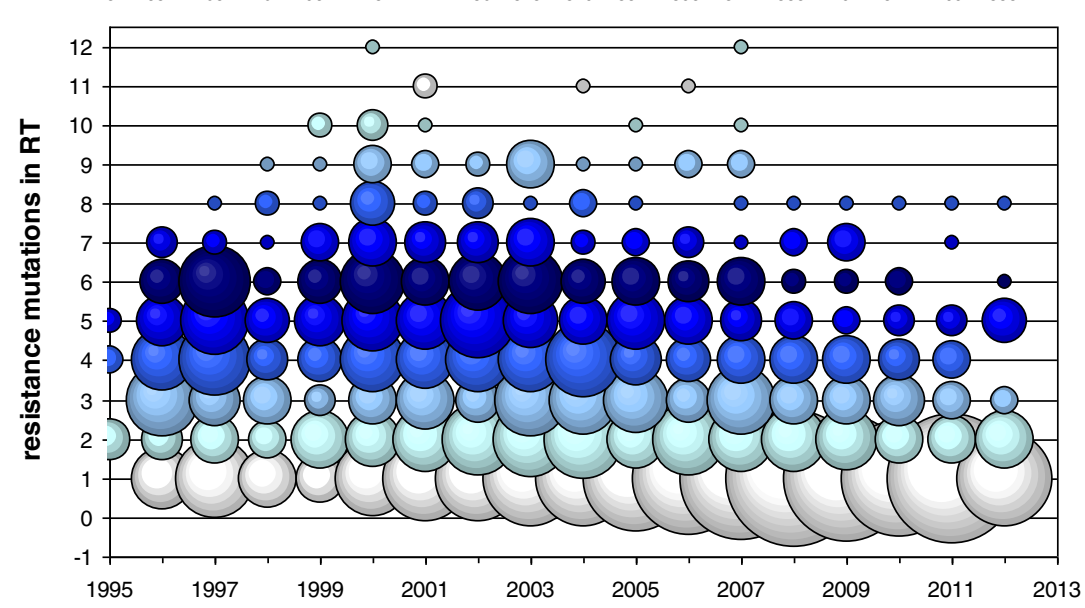

Figure 3 (See legend on next page.) 
(See figure on previous page.)

Figure 3 HIV drug resistance testing in the AMC. A. Percentage of key drug resistance mutations PR/RT in sequences from $1995-2012$.

Percentages of A (green), C (blue), U (red) and G (black) nucleotides are also shown. $\mathbf{B}$. The number of key drug resistance mutations in PR from

1995-2012. The size of the circles is correlated with the number of sequences in that category. $\mathbf{C}$. The number of key drug resistance mutations in

RT per sequence from 1995-2012. The size of the circles is correlated with the number of sequences in that category; colours were added

for clarity.

AIDS Cohort (MACS), initiated in 1983 at the Johns Hopkins School of Public Health, the University of Pittsburgh School of Public Health, Northwestern University School of Medicine, and the UCLA School of Public Health in the USA [35] and the Swiss HIV Cohort study (SHCS) that was established in 1988 in Switzerland [36]. Also, many cohort studies have been or are being performed in African countries, often in association with western universities.

\section{Drug-resistance mutations and HIV-1 evolution}

After the introduction of the first antiretroviral compounds into the clinic in 1987, it was realized that HIV can rapidly become resistant to single- or double-drug regimens. RT genotyping became part of the standard patient care followed by PR sequencing around 1995. It was implemented for patients failing on therapy or starting treatment, the latter such that optimal regimens could be installed. Also, there was a concern that drugresistant HIV-1 strains might be transmitted to become stable components of the epidemic. An in-house sequencing assay was used until 2001, when a commercial genotyping assay became available (Applied Biosystems ViroSeq HIV-1 Genotyping System [13,14]).

In the AMC, a total of $5266 \mathrm{PR} / \mathrm{RT}$ sequences from 4226 patients were determined between 1995 and 2012 that could be retrieved from the database. For most of the patients $(84.3 \%)$ a single PR/RT test was performed, but several patients (10.6\%) were tested repeatedly. Due to the early use of monotherapy combined with suboptimal patient adherence, drug-resistance mutations, estimated according to the Stanford University HIV drug resistance database [37], were observed in up to $88 \%$ of RT gene sequences in 1996 (Figure 3A). The numbers of HIV-1 sequences containing drug-resistance mutations, gradually decreased after the introduction of cART in 1996, and the decline continued after that time probably due to the introduction of better tolerated drug regimens and increased patient adherence.

The number of key mutations in PR (Figure 3B) and RT (Figure 3C) was plotted. HIV-1 sequences with multiple key mutations were observed mainly from 1998-2007 for RT and from 2000-2007 for PR, roughly coinciding with the clinical introduction of these drugs. However, data from more recent years $(>2009)$ indicate that sequences with more than 2 (PR) or 5 (RT) key mutations are observed less frequently, probably due to the development of optimized drug-regimens that improve therapy adherence and consequently plasma drug levels and antiviral activity. It thus seems that HIV-1 variants within the Amsterdam epidemic are not able to preserve these drug-related mutations, which may imply that there is a significant fitness cost involved and that compensating changes are rare [38]. We also described drug-dependent HIV-1 variants that will rapidly disappear in an epidemic upon transmission in the absence of the drug [39].

\section{A changing epidemic through import of novel HIV-1 variants}

Subtype B has always been the most prevalent HIV-1 subtype that circulated in the Netherlands [40], most likely imported through drug users from the USA to initiate the epidemic [41]. However, since the late 1990s several nonB subtypes have been detected, usually linked to immigration from HIV-endemic areas [42]. Subtype B continues to dominate the epidemic, but substantial numbers of patients are infected with CRF01_AE, CRF02_AG and subtype $C$ (Figure $4 \mathrm{~A}$ ). The latter two strains are mainly detected in heterosexual immigrants, while the former is present in MSM. Infections with untypable HIV-1 strains, including complex mosaic recombinant strains, are also on the rise from 2004 onwards with a steep ascend in 20082010 (Figure 4A). Subtype B strains are most prevalent in MSM, with very low percentages below $4 \%$ in other risk groups (Figure 4B). Of the non-B subtypes identified, 48\% are carried by MSM, 34\% by the heterosexual risk group, and $12 \%$ by children in the MTCT group (Figure 4B). HIV1 subtypes differ in replication kinetics [43], e.g. basal transcription levels vary [44], as well in the induction of disease progression $[45,46]$. It is therefore important for patient monitoring to analyze changes in subtype distribution over time.

A remarkable case was identified in our diagnostic unit in 2000. An HIV-1 infected patient from the Netherlands yielded an unusual HIV-1 genotype that did not cluster with subtype B or any of the other subtypes [47]. The patient had worked as sailor from 1985 till 1989 and was probably infected via a heterosexual contact in Africa or perhaps Asia. We presented the full-length genome sequence of this exotic HIV-1 variant and determined that the genetic distance with known subtypes fell within the range of intersubtype and intersubsubtype distances. Thus, we could not conclude on this isolate being a novel subtype, a subsubtype or an outlier variant of the most closely 


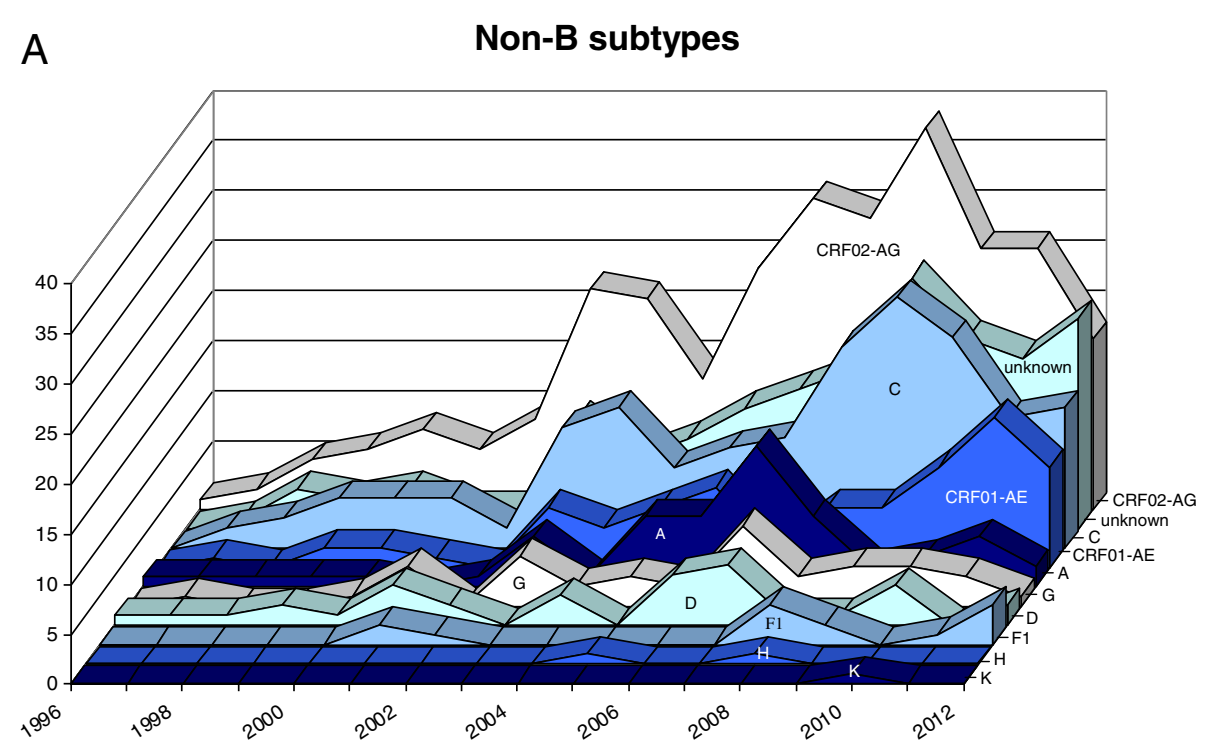

B
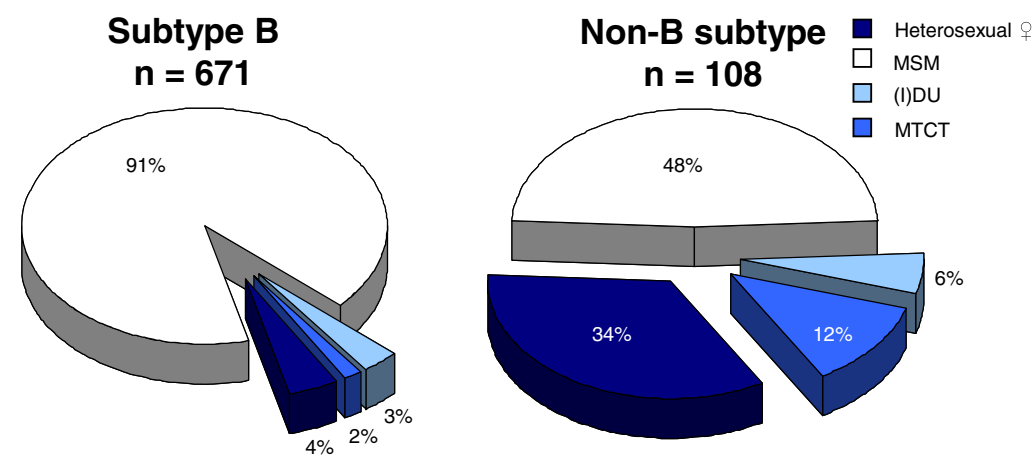

Figure 4 HIV-1 subtype distribution in the AMC. A. Numbers of HIV-1 non-B subtypes detected in patients visiting the AMC (Amsterdam, the Netherlands) from 1996-2012. "Unknown" consists of circulating recombinant forms (CRFs) other than CRF01_AE and CRF02_AG as well as difficult to type, complex mosaic strains and possible new subtypes. B. Percentages of HIV-1 B and non-B subtypes in the patient population according to the transmission risk group of HIV-1 that could be retrieved from the database. The total number of sequences $(\mathrm{N})$ analysed in each group is indicated.

related subtype K [47]. Similar sequences of other patients are needed to draw more firm conclusions and at least two epidemiologically unrelated patients with a similar HIV-1 variant are required to formally designate a new HIV-1 subtype. We also probed some biological properties of this virus, but did not reveal any particular assets. Because the patient was prescribed antiretroviral therapy, we were also able to monitor the appearance of drugresistance mutations, which did not reveal major differences with the regular subtype B viruses.

Overall, our sample set has become more enriched for exotic HIV-1 variants, which is illustrated by the steep increase in the number of untypable sequences in the regular PR/RT genotyping performed. Likewise, we see a steady increase in the number of non-B subtypes in Amsterdam.

\section{A changing epidemic, but is the virus changing?}

We described that the Dutch epidemic is changing with respect to the influx of new HIV-1 variants and subtypes. But is the virus that has spread in Amsterdam since 1983 also evolving? At the population level, one can monitor temporal trends in the pVL and CD4+ Tcell counts to reveal changes in the replication capacity and/or virulence of the respective HIV-1 strains. These values are important as they correlate with disease progression and the chance of HIV-1 transmission [12,48]. In Amsterdam, the set-point HIV-1 pVL of subtype B infected individuals was found to be higher in patients infected in more recent calendar years, with an accompanying decrease in CD4+ T-cell count $[49,50]$. Other studies have described similar trends [51-53], whereas 
others found no evidence for such temporal changes $[54,55]$.

To address this experimentally, we have measured the in vitro replication capacity or fitness of early versus late Amsterdam HIV-1 isolates. Changes in virulence and fitness of viral pathogens in epidemics are common. For HIV-1, increases in viral fitness have been reported within patients, while bottlenecks occurring during transmission can reduce the fitness [56,57]. Early replication studies suggested that HIV-1 attenuates over time within an epidemic, probably due to repeated serial transmission bottlenecks [58]. However, one should carefully match the early and late samples for viral subtype and duration of the infection. Twenty-five early and late HIV-1 subtype B isolates, carefully matched for seroconversion time, were tested in replication and competition assays on peripheral blood mononuclear cells [59]. We observed a clear trend of increasing fitness over time in the HIV-1 epidemic of Amsterdam. This in vitro virus characteristic may constitute one of the determinants of clinical virulence, but this will be hard to assess in this era of antiretroviral therapy.

We have also focused on the molecular description of genetic defects in viruses of patients with a particular low $\mathrm{pVL}$ and slow disease progression. Such genetic markers that correlate with delayed disease progression have been identified in several HIV-1 proteins (see references in [60]). The Amsterdam patient under study had a low pVL of less than 1000 copies $/ \mathrm{ml}$ for 2 years after seroconversion [60], which is observed in less than $1 \%$ of the individuals in the ACS cohort. This may suggest that the patient was infected with a poorly replicating virus. Indeed, a unique sequence insertion in the dimerization initiation site (DIS) of the untranslated 5' region of the HIV-1 RNA genome was found that abolished RNA dimerization, one of the molecular hallmarks of retroviral replication [60]. Subsequent changes over time restored this important RNA function, in line with an increase in the pVL to 50.000 copies $/ \mathrm{ml}$. The pVL measured at set-point [61] may be influenced by host genetic factors [62,63], but can clearly also be influenced by viral genetic factors. The mutations that influence pVL at set-point can be hidden in every part of the HIV-1 genome. More dramatic mutations and deletions can be detected by sequencing and comparing complete genomes from other patients.

\section{Ongoing HIV-1 evolution, but a stable nucleotide count}

Most virus genomes have a signature nucleotide composition, and HIV-1 is no exception, as its RNA genome is rich in A-nucleotides (approximately 35\%) and poor in Cnucleotides (approximately 18\%) [64-66]. Recently, we have described the extreme stability of this nucleotide composition over 30 years of evolution in the worldwide HIV-1 epidemic [67]. We plotted the nucleotide composition of
PR and RT, which are sensitive to antiretroviral drug pressure, from patient samples sequenced in Amsterdam between 1995 and 2012 (Figure 3A). The percentages of all four nucleotides were found to be extremely stable in this genomic region over this period, and similar to older HIV1 sequences. This suggests that during the Dutch epidemic HIV-1 is changing its virulence, but not its overall nucleotide composition. A recent study indicated that HIV-1 is able to replicate efficiently in cell culture after recoding parts of the gag or protease gene to reflect human codon usage [68]. These pilot results may suggest that changes in nucleotide composition do not always interfere with HIV replication capacity and can be tolerated. The major factor contributing to genome composition stability in HIV-1 remains to be elucidated.

\section{HIV-1 superinfections}

The large number of recombinant strains in the HIV-1 epidemic suggested already in the early years that dual infections with different HIV-1 strains should occur. Dual infections were supposed to occur before seroconversion, because the first HIV-1 infection could protect against subsequent infections. It took until 2002 before the first HIV-1 superinfections (= infection with a different strain after seroconversion) were reported [69-71]. We reported the first triple HIV-1 infection in 2005 [72]. This subtype $B$ infected patient was superinfected with a second subtype B strain and subsequently by a CRF01_AE strain. All three strains could be detected for several years in blood and seminal plasma, but the two superinfecting strains replicated to a higher level than the original virus [73].

We developed several methods to identify superinfections in clinical cohorts. The first method focused on patients with a sudden rise in $\mathrm{pVL}$ of at least 10-fold, which was found to predict superinfection in 2 of 14 patients [74]. Second, we described the use of degenerate base codes in the PR/RT genotyping sequence, which is a population sequence performed in routine clinical care. Multiple degenerate base code counts of $\geq 34$ were found to be a strong indicator of superinfection [75].

We were interested to study the clinical outcome of dually infected patients. Several pieces of evidence, based on in vitro virus replication studies, infection of animal models and mathematical modelling, suggest that superinfection leads to increased virulence and a higher $\mathrm{pVL}$ [76]. Virus competition experiments with HIV-1 subtype B strains from two superinfected patients suggested that the superinfecting strain has a significant replicative advantage over the initial strain [77]. Follow-up in a small cohort of patients suggested that dual infection is significantly associated with increased CD4+ T-cell decline ( $\mathrm{p}=0.0001$ in a multivariate analysis), and earlier start of antiretroviral therapy $(\mathrm{p}<0.0001)$ [78]. 
The incidence of HIV-1 dual infections is increasing in Amsterdam from an absence in early years to $1.0-2.4 \%$ in 2003-2007 [79,80]. The clinically unfavourable outcome of dual infection should translate into preventive strategies, in particular because dual infection is associated with risk-taking behaviour that has been reported to increase in recent years [81].

\section{More sensitive HIV-1 detection}

Although pVL is traditionally used as the biomarker of HIV-1 replication [82], the introduction of suppressive cART necessitated the development of alternative virological biomarkers for monitoring the therapy response, as pVL is undetectable by commercial assays in most of the cART-treated patients. In the ideal situation, such markers should be predictive of cART complications (e.g. therapy failure due to suboptimal adherence) and indicate the need for intervention, e.g. a change in drug-regimen. Quantitation of cell-associated (CA) HIV biomarkers provides an alternative to the measurements of pVL [83], but to be able to measure minute amounts of HIV nucleic acids in limited biological material from patients on suppressive cART, very sensitive assays are required.

We have developed sensitive and precise assays based on innovative semi-nested real-time PCR technology for quantitation of CA HIV unspliced (us) and multiply spliced RNA and total CA HIV DNA [84]. The addition of a limited-cycle preamplification step before the realtime PCR resulted in large improvements in both assay sensitivity and accuracy (especially in the lower quantitative range). This semi-nested real-time PCR is superior to the conventional single-step real-time PCR in the power of detection and quantitation of HIV-1 RNA and DNA [84]. Importantly, because we use only 15 cycles in the first PCR, preamplification does not interfere with the linearity of the standard curves throughout the whole range of serial dilutions $\left(R^{2}>0.99\right)$. The assay allows routine detection and quantitation of HIV RNA and DNA in the vast majority of PBMC samples of patients on cART with undetectable pVL [84-86]. Notably, this technology dramatically reduces the necessary amount of starting biologic material.

Using the semi-nested real-time PCR technology, we have shown that:

(i.) in untreated patients during the asymptomatic phase of HIV infection with steady-state plasma viremia, the levels of HIV-1 usRNA in PBMC increased significantly in time [87];

(ii.) in patients on suppressive cART, the levels of HIV1 usRNA in PBMC were predictive for therapy failure [85], an observation that was recently confirmed by an independent study that used a completely different assay for usRNA [88]; (iii.) in patients on ART with long-term virological success, modest nonadherence to ART caused significant longitudinal increase in the levels of usRNA in the absence of virological rebound in plasma [86];

(iv.) usRNA is a correlate of natural HIV control, as levels of usRNA in natural controllers were significantly lower than in patients on ART, while, importantly, T-cell proliferative responses to Gag and Pol peptides were higher [89].

These encouraging observations suggest that CA HIV-1 RNA is a significant and sensitive marker that allows monitoring the size and dynamics of the "active viral reservoir" in patients under cART. By contrast, total viral DNA is a marker of the "total viral reservoir", which consists mostly of infected, non-producing cells. Moreover, our results show that CA HIV-1 RNA is a significantly more sensitive correlate of viral control than pVL, at least when the latter is measured by an assay with a detection limit of 40-50 copies/ml.

\section{HIV-diagnostics in resource-limited settings}

The above described viral quantification method is a further example of the thriving merger between biomedical science and patient care in the Western world. However, assays like this are hardly applicable to resource-limited settings where most HIV-infected patients are living [90]. To be useful in these settings, methods should be low cost, low complexity and preferably avoid cold-storage requirements. HIV rapid tests that employ saliva to detect antibodies against HIV have greatly simplified HIV screening and early diagnosis in developing countries [22,90]. However, now that ART availability is expanding in the developing world, affordable methods to monitor treatment efficacy and virological failure are needed to avoid the spread of drug-resistant HIV strains [91]. Although portable CD4+ $\mathrm{T}$ cell counters are on the market for use in resource-limited settings, the CD4+ $\mathrm{T}$ cell count is not the most optimal parameter to monitor treatment failure (see: [90]). Viral load measurements are superior to CD4+ T-cell counts, but as blood plasma requires cold storage, dried blood spot-based technologies would be the method of choice (see: [90,92]). For instance, a simple real-time PCR method using dried blood spots has been developed and tested by the Affordable Resistance Test for Africa (ARTA) program, in which the AMC participates [93]. Dried blood spots can also be analysed for drug-resistance mutations [94], preferably using simplified methods that can be used locally [95].

\section{A single case of seroreversion}

As a retrovirus, HIV-1 induces a chronic infection that leads to a broad and well-sustained antibody response against multiple viral proteins. Seroconversion therefore 
occurs in all HIV-1 infected individuals, and antibody levels are maintained until the terminal AIDS phase in the majority of subjects. Seroreversion can be observed in noninfected children born to HIV-infected mothers that gradually loose their maternal antibodies $[96,97]$ and also in exceptional AIDS patients with little remaining B-cell activity [98], but not in the bulk of HIV-1 infected patients [99].

However, we reported HIV-1 seroreversion in a patient that was treated with cART during acute infection and with a fully reactive Western blot [100]. Another seroreversion case was reported in 2005 that was also treated with cART during primary infection. In this case, an incomplete HIV-1 antibody evolution pattern was revealed, suggesting that treatment was started before the antibody repertoire was completed [101]. Larger studies involving adult and young patients treated early in the infection suggested that HIV-1 seroreversion is not uncommon [102,103]. In contrast, seroreversion is rare in patients treated with cART later in infection, even when long-term undetectable $\mathrm{pVL}$ is achieved. One study reported no seroreversions in 80 patients tested [104] and another study found 1 out of 84 patients to have seroreverted [105].

\section{Conclusions}

The HIV-1 epidemic has triggered an evolution in patient care with the implementation of molecular biology techniques, which over 30 years have been optimized considerably. The careful collection of thousands of patient samples for these clinical tests has benefitted basic scientific research enormously, as illustrated for the AMC hospital in this review. Among the 50992 patients analyzed, we described unique HIV-1 variants in individual patients, including exotic mutants and unfamiliar strains. We performed studies to probe virus evolution, showing a rapidly changing pathogen (virulence, drug resistance, complex mosaic strains or undetermined subtypes), but at the same time very constant properties (genomic nucleotide composition). In return, molecular virology research allowed the development of novel diagnostics, including the ultra-sensitive detection of HIV-1 RNA in cells instead of plasma.

\section{Competing interests}

The authors declare that they have no competing interests.

\section{Authors' contributions}

$\mathrm{BB}$ conceived the review topic. BB, ACvdK and AOP drafted the manuscript. $M B$ analyzed the data from the HIV databases, and generated the figures. MC, SJ and NKTB helped drafting the manuscript. All authors read and approved the final manuscript.

\section{Acknowledgements}

The Amsterdam Cohort Studies on HIV infection and AIDS, a collaboration between the Public Health Service of Amsterdam, the Academic Medical Center of the University of Amsterdam, the Sanquin Blood Supply Foundation, the University Medical Center Utrecht, and the Jan van Goyen Medical Center are part of the Netherlands HIV Monitoring Foundation and financially supported by the Center for Infectious Disease Control of the Netherlands National Institute for Public Health and the Environment.

\section{Author details}

'Laboratory of Experimental Virology, Academic Medical Center of the University of Amsterdam, Amsterdam, the Netherlands. ${ }^{2}$ Department of Medical Microbiology, Laboratory of Clinical Virology, Center for Infection and Immunity Amsterdam (CINIMA), Academic Medical Center of the University of Amsterdam, Meibergdreef 15, 1105 AZ Amsterdam, the Netherlands.

Received: 23 May 2013 Accepted: 21 August 2013

Published: 28 August 2013

\section{References}

1. Jaffe HW, Bregman DJ, Selik RM: Acquired immune deficiency syndrome in the United States: the first 1,000 cases. J Infect Dis 1983, 148:339-345.

2. Barre-Sinoussi F, Chermann JC, Rey F, Nugeyre MT, Chamaret S, Gruest J, et al: Isolation of a T-Lymphotropic retrovirus from a patient at risk for Acquired Immune Deficiency Syndrome (AIDS). Science 1983, 220:868-871.

3. Gallo CR, Sarin PS, Gelmann EP, Robert-Guroff M, Richardson E, Kalyanaraman VS, et al: Isolation of Human T-Cell Leukemia Virus in Acquired Immune Deficiency Syndrome (AIDS). Science 1983, 220:865-867.

4. Ratner L, Haseltine W, Patarca R, Livak K, Starcich B, Josephs SF, et al: Complete nucleotide sequence of the AIDS virus, HTLV-III. Nature 1985, 313:277-284.

5. Wain-Hobson S, Sonigo P, Danos O, Cole S, Alizon M: Nucleotide sequence of the AIDS virus, LAV. Cell 1985, 40:9-17.

6. Kolata G: FDA approves AZT. Science 1987, 235:1570

7. van de Water HP, Bijleveld CC, Berkane M, Wiggers CC: Is the worst of the epidemic over? Back calculation of HIV seroprevalence in The Netherlands. Health Policy 1992, 21:211-221.

8. van Leeuwen R, Lange JM, Nijhuis M, Schuurman R, Reiss $P$, Danner SA, et al: Results of long-term follow-up of HIV-infected patients treated with lamivudine monotherapy, followed by a combination of lamivudine and zidovudine. Antivir Ther 1997, 2:79-90.

9. Vella S: HIV therapy advances. Update on a proteinase inhibitor. AIDS 1994, 8(3):S25-29.

10. Wit FW, van Leeuwen R, Weverling GJ, Jurriaans S, Nauta K, Steingrover R, et al: Outcome and predictors of failure of highly active antiretroviral therapy: one-year follow-up of a cohort of human immunodeficiency virus type 1-infected persons. J Infect Dis 1999, 179:790-798.

11. Fahey JL, Prince H, Weaver M, Groopman J, Visscher B, Schwartz K, et al: Quantitative changes in Thelper or T suppressor/cytotoxic lymphocyte subsets that distinguish acquired immune deficiency syndrome from other immune subset disorders. Am J Med 1984, 76:95-100.

12. Mellors JW, Rinaldo CR Jr, Gupta P, White RM, Todd JA, Kingsley LA: Prognosis in HIV-1 infection predicted by the quantity of virus in plasma. Science 1996, 272:1167-1170

13. Cunningham S, Ank B, Lewis D, Lu W, Wantman M, Dileanis JA, et al Performance of the applied biosystems ViroSeq human immunodeficiency virus type 1 (HIV-1) genotyping system for sequence-based analysis of HIV-1 in pediatric plasma samples. I Clin Microbiol 2001, 39:1254-1257.

14. Mracna M, Becker-Pergola G, Dileanis J, Guay LA, Cunningham S, Jackson JB, et al: Performance of Applied Biosystems ViroSeq HIV-1 Genotyping System for sequence-based analysis of non-subtype B human immunodeficiency virus type 1 from Uganda. J Clin Microbiol 2001, 39:4323-4327

15. Prummel MF, ten Berge RJ, Barrowclough H, Cejka V: Kaposi's sarcoma and fatal opportunistic infections in a homosexual man with immunodeficiency. Ned Tijdschr Geneeskd 1983, 127:820-824.

16. Zegerius L, Speelman JD: Cryptococcal meningitis, herpes genitalis and oral candidiasis in a homosexual man with acquired immunodeficiency. Ned Tijdschr Geneeskd 1983, 127:817-820.

17. Reiss P, Razenberg PP, de Geus JP, Schellekens PT: A patient with a mild form of the acquired immunodeficiency syndrome (AIDS). Ned Tijdsch Geneeskd 1983, 127:824-825.

18. Safai B, Sarngadharan MG, Groopman JE, Arnett K, Popovic M, Sliski A, et al: Seroepidemiological studies of human T-lymphotropic retrovirus type III in acquired immunodeficiency syndrome. Lancet 1984, 1:1438-1440.

19. Van der Bij AK, Mulder-Folkerts DK, van den Hoek JA, Boer K, Schutte MF, Coutinho RA: HIV-screening among pregnant women in the region of Amsterdam in 2002]. Ned Tijdschr Geneeskd 2003, 147:1232-1236. 
20. Op de Coul EL, Hahne S, van Weert YW, Oomen P, Smit C, van der Ploeg KP, et al: Antenatal screening for HIV, hepatitis B and syphilis in the Netherlands is effective. BMC Infect Dis 2011, 11:185.

21. Heijman RL, Stolte IG, Thiesbrummel HF, van Leent E, Coutinho RA, Fennema JS, et al: Opting out increases HIV testing in a large sexually transmitted infections outpatient clinic. Sex Transm Infect 2009, 85:249-255.

22. Hodinka RL, Nagashunmugam T, Malamud D: Detection of human immunodeficiency virus antibodies in oral fluids. Clin Diagn Lab Immunol 1998, 5:419-426.

23. Donker G, Dorsman S, Spreeuwenberg P, van den Broek I, van Bergen J: Twenty-two years of HIV-related consultations in Dutch general practice: a dynamic cohort study. BMJ Open 2013, 3:e001834

24. Ickenroth MH, Ronda G, Grispen JE, Dinant GJ, de Vries NK, van der Weijden T: How do people respond to self-test results? A cross-sectional survey. BMC Fam Pract 2010, 11:77

25. Jurriaans S, Back NK, Wolthers KC: Ten years of HIV testing with fourth generation assays: the Amsterdam experience. J Clin Virol 2011, 52(Suppl 1):S67-S69.

26. HIV Monitoring Foundation. http://www.hiv-monitoring.nl/index.php/nederlands/.

27. Goudsmit J, De Wolf F, Paul DA, Epstein LG, Lange JM, Krone WJ, et al: Expression of human immunodeficiency virus antigen (HIV-Ag) in serum and cerebrospinal fluid during acute and chronic infection. Lancet 1986, 2:177-180.

28. Lange JM, Paul DA, Huisman HG, De Wolf F, van den Berg H, Coutinho RA, et al: Persistent HIV antigenaemia and decline of HIV core antibodies associated with transition to AIDS. Br Med J (Clin Res Ed) 1986, 293:1459-1462.

29. Coutinho RA, Krone WJ, Smit L, Albrecht-van Lent P, van der Noordaa J, Schaesberg W, et al: Introduction of lymphadenopathy associated virus or human T lymphotropic virus (LAV/HTLV-III) into the male homosexual community in Amsterdam. Genitourin Med 1986, 62:38-43.

30. van Griensven GJ, Tielman RA, Goudsmit J, van der Noordaa J, De Wolf F, de Vroome EM, et al: Risk factors and prevalence of HIV antibodies in homosexual men in the Netherlands. Am J Epidemiol 1987, 125:1048-1057.

31. de Wolf F, Goudsmit J, Paul DA, Lange JM, Hooijkaas C, Schellekens P, et al: Risk of AIDS related complex and AIDS in homosexual men with persistent HIV antigenaemia. Br Med J (Clin Res Ed) 1987, 295:569-572.

32. Van der Knaap N, Grady BP, van der Loeff MF S, Heijman T, Speksnijder A, Geskus R, et al: Drug users in Amsterdam: are they still at risk for HIV? PLOS ONE 2013, 8:e59125

33. Lukashov W, Jurriaans S, Bakker M, Berkhout B: Transmission of risk-group specific HIV-1 strains among Dutch drug users for more than 20 years and their replacement by nonspecific strains after switching to lowharm drug practices. J Acquir Immune Defic Syndr 2013, 62:234-238.

34. Grijsen ML, Steingrover R, Wit FW, Jurriaans S, Verbon A, Brinkman K, et al: No treatment versus 24 or 60 weeks of antiretroviral treatment during primary HIV infection: the randomized Primo-SHM trial. PLoS Med 2012, 9:e1001 196.

35. Detels R, Jacobson L, Margolick J, Martinez-Maza O, Munoz A, Phair J, et al: The multicenter AIDS Cohort Study, 1983 to. Public Health 2012, 126:196-198.

36. Schoeni-Affolter F, Ledergerber B, Rickenbach M, Rudin C, Gunthard HF, Telenti A, et al: Cohort profile: the Swiss HIV Cohort study. Int J Epidemiol 2010, 39:1179-1189.

37. The Stanford University HIV drug resistance database. http://sierra2.stanford. edu/sierra/servlet/JSierra.

38. Berkhout B: HIV-1 evolution under pressure of protease inhibitors: climbing the stairs of viral fitness. J Biomed Sci 1999, 6:298-305.

39. Baldwin CE, Sanders RW, Deng Y, Jurriaans S, Lange JM, Lu M, et al: Emergence of a drug-dependent human immunodeficiency virus type 1 variant during therapy with the T20 fusion inhibitor. J Virol 2004, 78:12428-12437.

40. Paraskevis D, Pybus O, Magiorkinis G, Hatzakis A, Wensing AM, van de Vijver DA et al: Tracing the HIV-1 subtype B mobility in Europe: a phylogeographic approach. Retrovirology 2009, 6:49.

41. Lukashov W, Kuiken CL, Vlahov D, Coutinho RA, Goudsmit J: Evidence for HIV type 1 strains of U.S. intravenous drug users as founders of AIDS epidemic among intravenous drug users in northern Europe. AIDS Res Hum Retroviruses 1996, 12:1179-1183.

42. Op de Coul EL, Coutinho RA, van der Schoot A, van Doornum GJ, Lukashov W Goudsmit J, et al: The impact of immigration on env HIV-1 subtype distribution among heterosexuals in the Netherlands: influx of subtype B and non-B strains. AIDS 2001, 15:2277-2286.

43. Jeeninga RE, Hoogenkamp $M$, Armand-Ugon $M$, de Baar $M$, Verhoef $K$, Berkhout B: Functional differences between the long terminal repeat transcriptional promoters of human immunodeficiency virus type 1 subtypes A through G. J Virol 2000, 74:3740-3751.
44. van der Sluis RM, Pollakis G, van Gerven ML, Berkhout B, Jeeninga RE: Latency profiles of full length HIV-1 molecular clone variants with a subtype specific promoter. Retrovirology 2011, 8:73.

45. Pant PN, Shivkumar S, Cajas JM: Does genetic diversity of HIV-1 non-B subtypes differentially impact disease progression in treatment-naive HIV-1-infected individuals? A systematic review of evidence: 1996-2010. J Acquir Immune Defic Syndr 2012, 59:382-388.

46. Touloumi G, Pantazis N, Pillay D, Paraskevis D, Chaix ML, Bucher HC, et al: Impact of HIV-1 subtype on CD4 count at HIV seroconversion, rate of decline, and viral load set point in European seroconverter cohorts. Clin Infect Dis 2013, 56:888-897.

47. van der Hoek L, Pollakis G, Lukashov W, Jebbink MF, Jeeninga RE, Bakker M, et al: Characterization of an HIV-1 group $M$ variant that is distinct from the known subtypes. AIDS Res Hum Retroviruses 2007, 23:466-470.

48. Wawer MJ, Gray RH, Sewankambo NK, Serwadda D, Li X, Laeyendecker O, et al: Rates of HIV-1 transmission per coital act, by stage of HIV-1 infection, in Rakai, Uganda. J Infect Dis 2005, 191:1403-1409.

49. Gras L, Jurriaans S, Bakker M, van Sighem A, Bezemer D, Fraser C, et al: Viral load levels measured at set-point have risen over the last decade of the HIV epidemic in the Netherlands. PLOS ONE 2009, 4:e7365.

50. Gras L, Geskus RB, Jurriaans S, Bakker M, van Sighem A, Bezemer D, et al: Has the rate of CD4 cell count decline before initiation of antiretroviral therapy changed over the course of the Dutch HIV epidemic among MSM? PLOS ONE 2013, 8:e64437. accepted for publication.

51. Muller V, Maggiolo F, Suter F, Ladisa N, De LA, Antinori A, et al: Increasing clinical virulence in two decades of the Italian HIV epidemic. PLoS Pathog 2009, 5:e1000454.

52. Dorrucci M, Rezza G, Porter K, Phillips A: Temporal trends in postseroconversion CD4 cell count and HIV load: the Concerted Action on Seroconversion to AIDS and Death in Europe Collaboration, 19852002. J Infect Dis 2007, 195:525-534.

53. Crum-Cianflone N, Eberly L, Zhang Y, Ganesan A, Weintrob A, Marconi V, et al: Is HIV becoming more virulent? Initial CD4 cell counts among HIV seroconverters during the course of the HIV epidemic: 1985-2007. Clin Infect Dis 2009, 48:1285-1292

54. Muller V, Ledergerber B, Perrin L, Klimkait T, Furrer $H$, Telenti A, et al: Stable virulence levels in the HIV epidemic of Switzerland over two decades. AIDS 2006, 20:889-894

55. Herbeck JT, Gottlieb GS, Li X, Hu Z, Detels R, Phair J, et al: Lack of evidence for changing virulence of HIV-1 in North America. PLOS ONE 2008, 3:e1525.

56. Quinones-Mateu ME, Ball SC, Marozsan AJ, Torre VS, Albright JL, Vanham G, et al: A dual infection/competition assay shows a correlation between ex vivo human immunodeficiency virus type 1 fitness and disease progression. J Virol 2000, 74:9222-9233.

57. Troyer RM, Collins KR, Abraha A, Fraundorf E, Moore DM, Krizan RW, et al: Changes in human immunodeficiency virus type 1 fitness and genetic diversity during disease progression. J Virol 2005, 79:9006-9018

58. Arien KK, Troyer RM, Gali Y, Colebunders RL, Arts EJ, Vanham G: Replicative fitness of historical and recent HIV-1 isolates suggests HIV-1 attenuation over time. AIDS 2005, 19:1555-1564.

59. Gali Y, Berkhout B, Vanham G, Bakker M, Back NK, Arien KK: Survey of the temporal changes in HIV-1 replicative fitness in the Amsterdam cohort. Virology 2007, 364:140-146.

60. Huthoff $H$, Das AT, Vink M, Klaver B, Zorgdrager $F$, Cornelissen $M$, et al: A human immunodeficiency virus type 1-infected individual with low viral load harbors a virus variant that exhibits an in vitro RNA dimerization defect. J Virol 2004, 78:4907-4913.

61. Fraser C, Hollingsworth TD, Chapman R, de Wolf F, Hanage WP: Variation in HIV-1 set-point viral load: epidemiological analysis and an evolutionary hypothesis. Proc Natl Acad Sci USA 2007, 104:17441-17446.

62. Fellay J, Shianna KV, Ge D, Colombo S, Ledergerber B, Weale M, et al: A whole-genome association study of major determinants for host control of HIV-1. Science 2007, 317:944-947.

63. Fellay J, Ge D, Shianna KV, Colombo S, Ledergerber B, Cirulli ET, et al: Common genetic variation and the control of HIV-1 in humans. PLoS Genet 2009, 5:e1000791.

64. Kypr J, Mrazek J, Reich J: Nucleotide composition bias and CpG dinucleotide content in the genomes of HIV and HTLV $1 / 2$. Biochim Biophys Acta 1989, 1009:280-282. 
65. Bronson EC, Anderson JN: Nucleotide composition as a driving force in the evolution of retroviruses. J Mol Evol 1994, 38:506-532.

66. Berkhout B, van Hemert FJ: The unusual nucleotide content of the HIV RNA genome results in a biased amino acid composition of HIV proteins. Nucleic Acids Res 1994, 22:1705-1711.

67. van der Kuyl AC, Berkhout B: The biased nucleotide composition of the HIV genome: a constant factor in a highly variable virus. Retrovirology 2012, 9:92.

68. Martrus G, Nevot M, Andres C, Clotet B, Martinez MA: Changes in codon-pair bias of human immunodeficiency virus type 1 have profound effects on virus replication in cell culture. Retrovirology 2013, 10:78.

69. Ramos A, Hu DJ, Nguyen L, Phan KO, Vanichseni S, Promadej N, et al: Intersubtype human immunodeficiency virus type 1 superinfection following seroconversion to primary infection in two injection drug users. J Virol 2002, 76:7444-7452.

70. Jost S, Bernard MC, Kaiser L, Yerly S, Hirschel B, Samri A, et al: A patient with HIV-1 superinfection. N Engl J Med 2002, 347:731-736.

71. Altfeld M, Allen TM, Yu XG, Johnston MN, Agrawal D, Korber BT, et al: HIV-1 superinfection despite broad CD8+ T-cell responses containing replication of the primary virus. Nature 2002, 420:434-439.

72. van der Kuyl AC, Kozaczynska K, Van den Burg R, Zorgdrager F, Back N, Jurriaans S, et al: Triple HIV-1 infection. New England Journal of Medicine 2005, 352:2557-2559.

73. Kozaczynska K, Cornelissen M, Reiss P, Zorgdrager F, van der Kuyl AC: HIV-1 sequence evolution in vivo after superinfection with three viral strains. Retrovirology 2007, 4:59.

74. Jurriaans S, Kozaczynska K, Zorgdrager F, Steingrover R, Prins JM, van der Kuyl AC, et al: A sudden rise in viral load is infrequently associated with HIV-1 superinfection. JAIDS 2008, 47:69-73.

75. Cornelissen M, Jurriaans S, Kozaczynska K, Prins JM, Hamidjaja RA, Zorgdrager $F$, et al: Routine HIV-1 genotyping as a tool to identify dual infections. AIDS 2007, 21:807-811.

76. Hoogmoed D, Cornelissen M, van der Kuyl AC: Clinical relevance of HIV-1 superinfection. In HIV-host interactions. Edited by Chang TL. Croatia: InTech Europe; 2011:79-96.

77. van der Kuyl AC, Kozaczynska K, Arien KK, Gali Y, Balazs VR, Dekker SJ, et al: Analysis of infectious virus clones from two HIV-1 superinfection cases suggests that the primary strains have lower fitness. Retrovirology 2010, 7:60.

78. Cornelissen M, Pasternak AO, Grijsen ML, Zorgdrager F, Bakker M, Blom P, et al: HIV-1 dual infection is associated with faster CD4+ T-cell decline in a cohort of men with primary HIV infection. Clin Infect Dis 2012, 54:539-547.

79. Rachinger A, Stolte IG, Derks van de Ven T, Burger JA, Prins M, Schuitemaker $H$, et al: Absence of HIV-1 superinfection 1 year after infection between 1985 and 1997 coincides with a reduction in sexual risk behavior in the seroincident Amsterdam cohort of homosexual men. Clin Infect Dis 2010, 50:1309-1315

80. van der Kuyl AC, Zorgdrager F, Jurriaans S, Back NK, Prins JM, Brinkman K, et al: Incidence of human immunodeficiency virus type 1 dual infections in Amsterdam, The Netherlands, during 2003-2007. Clin Infect Dis 2009, 48:973-978

81. Heijman T, Geskus RB, Davidovich U, Coutinho RA, Prins M, Stolte IG: Less decrease in risk behaviour from pre-HIV to post-HIV seroconversion among MSM in the combination antiretroviral therapy era compared with the precombination antiretroviral therapy era. AIDS 2012, 26:489-495.

82. Siliciano JD, Siliciano RF: Biomarkers of HIV replication. Curr Opin HIV AIDS 2010, 5:491-497.

83. Pasternak AO, Lukashov W, Berkhout B: Cell-associated HIV RNA: a dynamic biomarker of viral persistence. Retrovirology 2013, 10:41.

84. Pasternak AO, Adema KW, Bakker M, Jurriaans S, Berkhout B, Cornelissen M, et al: Highly sensitive methods based on seminested real-time reverse transcription-PCR for quantitation of human immunodeficiency virus type 1 unspliced and multiply spliced RNA and proviral DNA. J Clin Microbiol 2008, 46:2206-2211.

85. Pasternak AO, Jurriaans S, Bakker M, Prins JM, Berkhout B, Lukashov W: Cellular levels of HIV unspliced RNA from patients on combination antiretroviral therapy with undetectable plasma viremia predict the therapy outcome. PLOS ONE 2009, 4:e8490.

86. Pasternak $A O$, de Bruin $M$, Jurriaans $S$, Bakker $M$, Berkhout $B$, Prins JM, et al: Modest nonadherence to antiretroviral therapy promotes residual HIV-1 replication in the absence of virological rebound in plasma. $J$ Infect Dis 2012, 206:1443-1452
87. Pasternak AO, Jurriaans S, Bakker M, Berkhout B, Lukashov W: Steady increase in cellular HIV-1 load during the asymptomatic phase of untreated infection despite stable plasma viremia. AIDS 2010, 24:1641-1649.

88. Shults K, Flye-Blakemore L, Patterson BK, Elbeik T: Analysis of multiple cell reservoirs expressing unspliced HIV-1 gag-pol mRNA in patients on antiretroviral therapy. Future Virol 2012, 7:819-832.

89. Van Gulck E, Bracke L, Heyndrickx L, Coppens S, Atkinson D, Merlin C, et al: Immune and viral correlates of "secondary viral control" after treatment interruption in chronically HIV-1 infected patients. PLOS ONE 2012, 7:e37792.

90. Wu G, Zaman MH: Low-cost tools for diagnosing and monitoring HIV infection in low-resource settings. Bull World Health Organ 2012, 90:914-920.

91. Wainberg MA: Two standards of care for HIV: why are Africans being short-changed? Retrovirology 2009, 6:109.

92. Roberts T, Bygrave H, Fajardo E, Ford N: Challenges and opportunities for the implementation of virological testing in resource-limited settings. $J$ Int AIDS Soc 2012, 15:17324

93. Aitken SC, Kliphuis A, Bronze M, Wallis CL, Kityo C, Balinda S, et al: Development and evaluation of an affordable real-time qualitative assay for determining HIV-1 virological failure in plasma and dried blood spots. J Clin Microbiol 2013, 51:1899-1905.

94. Arnedo M, Alonso E, Eisenberg N, Ibanez L, Ferreyra C, Jaen A, et al: Monitoring HIV viral load in resource limited settings: still a matter of debate? PLOS ONE 2012, 7:e47391.

95. Aitken SC, Bronze M, Wallis CL, Stuyver L, Steegen K, Balinda S, et al: A pragmatic approach to HIV-1 drug resistance determination in resource-limited settings by use of a novel genotyping assay targeting the reverse transcriptase-encoding region only. J Clin Microbiol 2013, 51:1757-1761.

96. Lepage $P$, Van de Perre $P$, Simonon A, Msellati P, Hitimana DG, Dabis F: Transient seroreversion in children born to human immunodeficiency virus 1-infected mothers. Pediatr Infect Dis J 1992, 11:892-894.

97. Chantry CJ, Cooper ER, Pelton SI, Zorilla C, Hillyer GV, Diaz C: Seroreversion in human immunodeficiency virus-exposed but uninfected infants. Pediatr Infect Dis J 1995, 14:382-387.

98. Gutierrez M, Soriano V, Bravo R, Vallejo A, Gonzalez-Lahoz J: Seroreversion in patients with end-stage HIV infection. Vox Sang 1994, 67:238-239.

99. Roy MJ, Damato JJ, Burke DS: Absence of true seroreversion of HIV-1 antibody in seroreactive individuals. JAMA 1993, 269:2876-2879.

100. Jurriaans S, Sankatsing SU, Prins JM, Schuitemaker H, Lange J, van der Kuyl AC, et al: HIV-1 seroreversion in an HIV-1-seropositive patient treated during acute infection with highly active antiretroviral therapy and mycophenolate mofetil. AIDS 2004, 18:1607-1608.

101. Kassutto S, Johnston MN, Rosenberg ES: Incomplete HIV type 1 antibody evolution and seroreversion in acutely infected individuals treated with early antiretroviral therapy. Clin Infect Dis 2005, 40:868-873.

102. Hainaut M, Peltier CA, Goetghebuer T, Van der LD, Marissens D, Zissis G, et al: Seroreversion in children infected with HIV type 1 who are treated in the first months of life is not a rare event. Clin Infect Dis 2005, 41:1820-1821.

103. Hare CB, Pappalardo BL, Busch MP, Karlsson AC, Phelps BH, Alexander SS, et al: Seroreversion in subjects receiving antiretroviral therapy during acute/early HIV infection. Clin Infect Dis 2006, 42:700-708.

104. Cornelissen M, Jurriaans S, Prins JM, Bakker M, van der Kuyl AC: Absence of seroreversion in 80 HAART-treated HIV-1 seropositive patients with at least five-years undetectable plasma HIV-1 viral load. AIDS Res Ther 2006, 3:3.

105. Amor A, Toro C, Jimenez V, Simon A, Ramos B, Soriano V: Seroreversion of HIV antibodies in patients with prolonged suppression of viraemia under HAART. AIDS 2006, 20:1460-1462

\section{doi:10.1186/1742-4690-10-93}

Cite this article as: van der Kuyl et al:: Translational HIV-1 research: from routine diagnostics to new virology insights in Amsterdam, the Netherlands during 1983-2013. Retrovirology 2013 10:93. 